\title{
THE PULMONARY ARTERIES AND ARTERIOLES IN HYALINE MEMBRANE DISEASE
}

\author{
BY \\ J. L. TH. OEBERIUS KAPTEYN, G. G. WOLVIUS and C. A. WAGENVOORT \\ From the Pathological Laboratory, Leiden University, and the Department of Paediatrics, \\ Zuiderziekenhuis, Rotterdam, Holland
}

(RECEIVED FOR PUBLICATION FEBRUARY 28, 1963)

The pathogenesis of hyaline membrane disease is not only unsolved but also highly controversial and 'there exist almost as many theories about it as there have been serious observers' (Stowens, 1959). Among these theories some are based on the assumption that circulatory disturbances play a role in the development of the hyaline membranes. Transudation of constituents of blood plasma has been considered a factor in this process by many authors (Hadders and Dirken, 1955; Jarrett, 1957; van Breemen, Neustein and Bruns, 1957; Piper and Kleppe, 1958; Engelhardt, 1961). Alveolar capillary congestion and pulmonary oedema are commonly observed in lungs of infants with pulmonary hyaline membranes (Ziegler, 1957; Shanklin, 1959; Carone and Spector, 1960): this may be due to damage to the capillary wall resulting in increased capillary permeability. However, the exceedingly common, although not exclusive, association of hyaline membrane disease of the lung with prematurity has led some workers to believe that the lack of maturity of pulmonary tissue may play a role in such an increased permeability (Brummelkamp, 1958; Goebel, Koburg and Thelen, 1962). Others (O'Neal, Ahlvin, Bauer and Thomas, 1957) have noticed that the media of muscular pulmonary arteries and arterioles in premature infants is less well developed as compared to that in full-term newborns and suggested that this may be a factor in the development of hyaline membranes.

Rudolph, Drorbaugh, Auld, Rudolph, Nadas, Smith and Hubbell (1961), who performed cardiac catheterization in a number of infants with hyaline membrane disease, suggested that there was decreased vasoconstrictive activity both in systemic and pulmonary circulation. In a quantitative study of the medial muscle mass of pulmonary arteries in foetuses and infants, one of us (Wagenvoort, Neufeld and Edwards, 1961) showed that normally there is a gradual increase in the amount of pul- monary arterial muscle tissue during foetal life, with a maximum at the time of birth. In other words, the media of pulmonary arteries and arterioles in premature infants is not yet fully developed. If this fact should in any way be related to the pathogenesis of hyaline membrane disease, we may expect that, on the average, infants with this form of respiratory distress should have a smaller arterial muscle mass than infants of similar gestational age without this disease.

In this study we have compared the thickness of the media and the total amount of medial muscle tissue of premature infants having hyaline membrane disease with that in premature infants who died of other causes, in order to see if the pulmonary arteries in the first group differ in any respect from a normal control series.

\section{Material and Methods}

The lungs of eight infants who died of hyaline membrane disease and of five infants who died of other causes were studied. The gestational age of the first group varied from 26 to 34 weeks, and of the control group from 25 to 37 weeks. The postnatal survival period in the infants with hyaline membrane disease ranged from seven hours to two days, and in the control infants from five hours to five days. The cause of death in the control group included cerebral haemorrhage, asphyxia, septicaemia and immaturity. In none of the cases of either group were there congenital cardiovascular anomalies.

Blocks were taken from five segments usually of the right lung. (In one case the left lung was used, since the right lung was damaged at autopsy.) These five segments were the apical and anterior segments of the upper lobe, middle lobe or lingula and apical and anterobasal segments of the lower lobe. Generally, in order to get a block sufficiently large for quantitative study, parts of adjacent segments were included in the block. The blocks were embedded in paraffin, and sections were stained by haematoxylin and eosin and by Lawson's elastic stain counterstained by van Gieson. 
TABLE

\begin{tabular}{|c|c|c|c|c|c|c|}
\hline & & No. & $\begin{array}{c}\text { Gestational Age } \\
\text { (wks.) }\end{array}$ & $\begin{array}{c}\text { Postnatal } \\
\text { Survival }\end{array}$ & $\begin{array}{l}\text { Mean Relative } \\
\text { Medial Thickness }\end{array}$ & $\begin{array}{l}\text { Index of Medial } \\
\text { Cross-sectional Area }\end{array}$ \\
\hline Controls $\quad \ldots$ & $\cdots$ & $\begin{array}{l}1 \\
2 \\
3 \\
4 \\
5\end{array}$ & $\begin{array}{l}25 \\
37 \\
32 \\
25 \\
26\end{array}$ & $\begin{aligned} 5 & \text { days } \\
2 & \text { days } \\
12 & \text { hrs } \\
3-4 & \text { hrs } \\
4 & \text { days }\end{aligned}$ & $\begin{array}{l}16 \cdot 6 \\
17 \cdot 1 \\
14 \cdot 0 \\
17 \cdot 8 \\
13 \cdot 6\end{array}$ & $\begin{array}{l}329 \\
225 \\
177 \\
264 \\
180\end{array}$ \\
\hline Hyaline membrane disease & $\cdots$ & $\begin{array}{r}6 \\
7 \\
8 \\
9 \\
10 \\
11 \\
12 \\
13\end{array}$ & $\begin{array}{l}26 \\
27 \\
32 \\
34 \\
29 \\
28 \\
25 \\
25\end{array}$ & $\begin{array}{r}10 \mathrm{hrs} \\
18 \mathrm{hrs} \\
1 \mathrm{day} \\
40 \mathrm{hrs} \\
12 \mathrm{hrs} \\
14 \mathrm{hrs} \\
36 \mathrm{hrs} \\
7 \mathrm{hrs}\end{array}$ & $\begin{array}{l}19 \cdot 2 \\
17 \cdot 9 \\
18 \cdot 3 \\
17 \cdot 2 \\
16 \cdot 6 \\
20 \cdot 8 \\
18 \cdot 2 \\
17 \cdot 2\end{array}$ & $\begin{array}{l}284 \\
335 \\
287 \\
176 \\
247 \\
308 \\
263 \\
246\end{array}$ \\
\hline
\end{tabular}

The method employed for our quantitative studies has been described in detail elsewhere (Wagenvoort, 1960). The thickness of the media and the external diameter of 100 muscular pulmonary arteries, chosen at random, but of a virtually circular cross-section, are measured. From these data the relative medial thickness, i.e. the medial thickness expressed as a percentage of the external diameter of the artery, can be determined.

Determination of the mean relative medial thickness leaves undecided whether increase or decrease of medial thickness is caused by a change in the amount of medial tissue or by the functional state of the vessel, i.e. its degree of constriction or dilatation. To establish this, the surface area of the medial tissue of individual arteries and subsequently the ratio in cross-sectional area of medial tissue to pulmonary parenchyma has been calculated. This ratio gives a determination of the amount of medial muscle tissue in the lung. It has been expressed

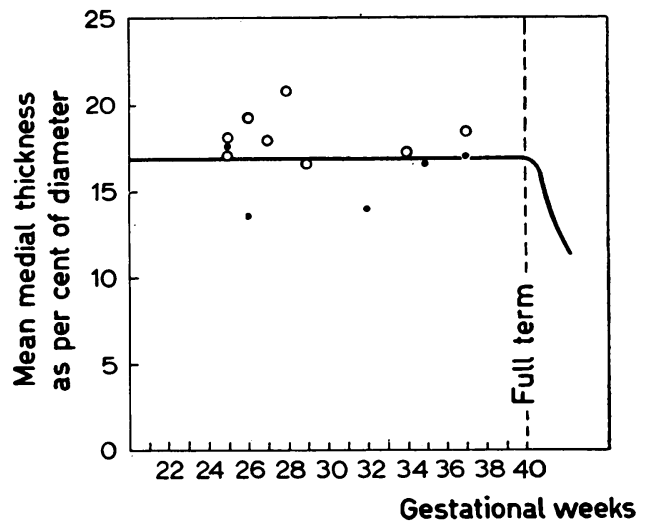

\section{- - Normal controls \\ o- Hyaline membrane disease}

Fig. 1.-Diagram of mean medial thickness of muscular pulmonary arteries expressed as percentage of external diameter plotted against the gestational age, both in normal control cases and in cases of hyaline membrane disease. The black line is the composite expression of such data obtained in an earlier and larger group of normal control cases (Wagenvoort et al., 1961). as an index and will be referred to as the index of the medial surface area. An increase in this index indicates medial hypertrophy and vice versa. This, in principle, is independent of an eventual arterial constriction.

\section{Results and Comment}

The results of our quantitative studies are shown in the Table. In general the mean relative medial thickness in the control group conforms to earlier data obtained in a similar but larger group of normal infants (Wagenvoort et al., 1961) (Fig. 1). The same applies to the index of the medial surface area (Fig. 2). As is shown in these figures and in the Table, the results, both for mean medial thickness and for index of medial surface area in infants

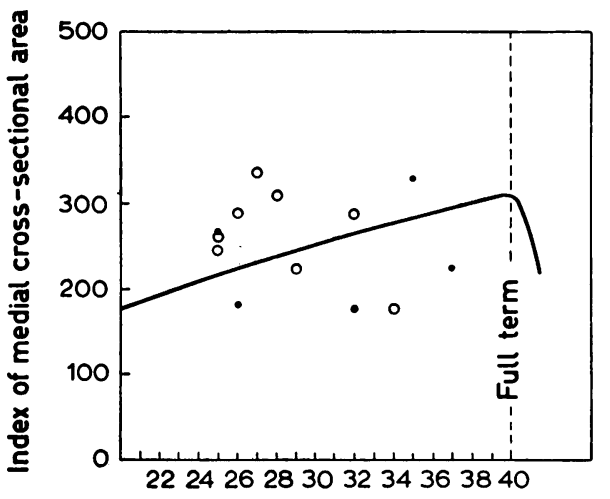

Gestational weeks

\section{- Normal controls \\ - Hyaline membrane disease}

Fig. 2.-Diagram of index of medial cross-sectional area (that is cross-sectional area of media per unit of lung tissue), plotted against the gestational age, both in normal control cases and in cases of hyaline membrane disease. The black line is the composite expression of such data obtained in an earlier and larger group of normal control cases (Wagenvoort et al., 1961). 
who died of pulmonary hyaline membrane disease, do not differ significantly from those in our normal control group.

In general, the results obtained in this study are consistent with our earlier finding (Wagenvoort et al., 1961) that premature infants, generally, have a medial muscle mass of their pulmonary arteries, which is less developed than that in full-term infants.

It appears, however, that the pulmonary arterial media in premature infants with hyaline membrane disease of the lungs does not differ significantly from that in premature infants who died of other causes. There is certainly no indication for a decreased pulmonary arterial muscle mass in cases of hyaline membrane disease as compared to normal controls. Therefore, it is unlikely that underdevelopment of pulmonary arterial muscle tissue is a factor in the pathogenesis of hyaline membrane disease.

\section{Summary}

The thickness of the media and the amount of medial muscle tissue of muscular pulmonary arteries was studied quantitatively in eight premature infants who died of pulmonary hyaline membrane disease.

The data were compared with those of normal premature infants. It is shown that in hyaline membrane disease the pulmonary arterial media does not differ with regard to its thickness or to the amount of its muscular tissue from that in normal infants. This suggests that lack of maturity of these vessels is not basic to the condition of hyaline membrane disease, as has been supposed in earlier published reports.

\section{REFERENCES}

Brummelkamp, W. H. (1958). Hyaliene membranen in de longen van pasgeborenen. Ned. T. Geneesk, 102, 662.

Carone, F. A. and Spector, W. G. (1960). The interaction of plasma proteins and mucoid substances in the pathogenesis of pulmonary hyaline membranes. J. Path. Bact., 80, 63.

Engelhardt, J. (1961). Een poging tot behandeling van de hyalienemembranenpneumonie. Ned. T. Geneesk, 105, 1813.

Goebel, A., Koburg, E. and Thelen, H. (1962). UUber Zusammenhänge zwischen der Lokalisation und der Entstehung pulmonaler hyaliner Membranen bei Frühgeborenen. Frankfurt. Z. Path. 72,111 .

Hadders, H. N. and Dirken, M. N. J. (1955). On the origin of the pulmonary hyaline membranes. J. Path. Bact., 70, 419.

Jarrett, W. F. H. (1957). A histochemical study of pulmonary hyaline membranes in cattle. ibid., 74, 444.

O'Neal, R. M., Ahlvin, R. C., Bauer, W. C. and Thomas, W. A (1957). Development of fetal pulmonary arterioles. Arch. Path., 63, 309.

Piper, P. G. and Kleppe, L. W. (1958). Hyaline-membrane disease in the newborn associated with a lower accessory lung. ibid., 65,131 .

Rudolph, A. M., Drorbaugh, J. E., Auld, P. A. M., Rudolph, A. J., Nadas, A. S., Smith, C. A. and Hubbell, J. P. (1961). Studies on the circulation in the neonatal period. The circulation in the respiratory distress syndrome. Pediatrics, 27, 551 .

Shanklin, D. R. (1959). Cardiovascular factors in development of pulmonary hyaline membrane. Arch. Path., 68, 49.

Stowens, D. (1959). Pediatric Pathology. Williams and Wilkins, Baltimore.

van Breemen, V. L., Neustein, H. B. and Bruns, P. D. (1957). Pulmonary hyaline membranes studied with the electron microscope. monary hyaline membran

Wagenvoort, C. A. (1960). Vasoconstriction and medial hypertrophy in pulmonary hypertension. Circulation, 22, 535.

- Neufeld, H. N. and Edwards, J. E. (1961). The structure of the pulmonary arterial tree in fetal and early postnatal life. Lab. Invest., 10,751 .

Ziegler, H. K. (1957). Die hyalinen Membranen im Rahmen der Lungenbefunde bei Frühgeborenen. $Z$. Kinderheilk., 79, 433. 